Acta Universitatis Sapientiae, Philologica, 8, 3 (2016) 53-59

DOI: 10.1515/ausp-2016-0031

\title{
Expansion Patterns of the Terminological Metaphor
}

\author{
Doina BUTIURCA \\ Sapientia Hungarian University of Transylvania \\ Faculty of Technical and Human Sciences, Târgu-Mureş \\ Department of Applied Linguistics \\ butiurcadoina@yahoo.com
}

\begin{abstract}
The assertion our research starts from is that medical terms coined from Greek and Latin scientific elements denote notions, offer information on the level of specialized communication, updating without any exceptions at least two associated preconceptual patterns. From a cognitive perspective, the group of terms has developed based on logical relations of interaction, the starting point of which can be always identified in the cultural and anthropological elements in the environmental, cosmic, etc. dimension of human existence. The arborescent coherence on the level of the terminological corpus, the associated preconceptual patterns and the metaphor through polilexical interaction, the cognitive and informative function of the metaphor on the level of the domain/subdomain and on the level of titling are only some of the objectives this research aims to achieve. I mostly apply the descriptive linguistic method as well as the cognitive, analytical, and comparative methods.

Conclusions: the scientific compounds have been coined based on an "associated preconceptual pattern". Through their special linguistic and semasiological behaviour, the scientific compounds have become a source of neonymy in the Pan-Latin lexicon.
\end{abstract}

Keywords: terminology, scientific compounds, coherence, titling

\section{The arborescent coherence of the corpus of terms}

The description of a concept or of a metaphorical construct through expansion consists of the listing of all possible realizations of the given concept. All concepts based on the Gr. nyx, nyktos ('night') model have been formed through expansion: nyctalgia [the expansion of the meaning in the sphere of diseases] // nyctalopia (controversial concept in French/English medicine: it designates the human 
capacity to see at night - in French medicine/night-blindness in English and Romanian medicine); // nychthemeron (conceptual expansion of the biological cycle of one day and one night of the human being)]; nychthemeral (expansion of characteristic); // nyctophobia (conceptual expansion on the branch of phobias).

The metaphor of a Greek and Latin origin retains its status of a metaphorical construct in its derivatives, in the scientific compounds, in polylexical constructs, etc. It is the sine qua non condition of developing the terminological corpus/ of the specialization of a subdomain/of a branch, etc. The cultural/ontological model is the creator of one of the most complex notions, based on which special languages have developed in a coherent and unified way: Lat. granum, i (n) "grain" had the diminutive Lat. granulum, successfully used with the meaning of "tiny seed". While studying the metaphorical constructs generated by the Lat. granulum model, the heuristic consequence can also be analysed ["intracellular corpuscles"] using logical reasoning:

1. An intracellular particle (in anatomy) is a grain (the vegetal model) - med. Ro. granulă: see Fr. granule/En. granule;

2. In symptomatology, a corpuscle/an inclusion/a formation reduced in size is a grain localized in cells/bacteria/tissue - med. Ro. granulație (cf. Fr. granulation/ Eng. granulation); // it might be a "grey granulation" located in the lungs - meaning a granulitis: (cf. Fr. med. granulie; En. granulitis) - a metaphorical expansion of the same vegetal model (Lat. granulum).

3. The surface of a tissue is a succession of tiny seeds, if it refers to the metaphorical constructs designating the types of tissues: med. Ro. granulos (cf. Fr. granuleux, - euse, adj./Eng. granulous). In compounds, granum generates numerous cognitive constructs through interaction: med. Ro. granuloblastom (cf. Fr. granuloblastome; En. neuroblastoma); med. Ro. granulocitoză (cf. Fr. granulocytose; En. granulocytosis); med. Ro. granulopexic (cf. Fr. granulopexique, adj.; En. granulopexic), med. Ro. granulocitopenie (cf. Fr. granulopénie; En. granulopenia), etc. The medical language has formed based on an impressive number of preconceptual patterns, which expanded into compounds, and metaphorical syntagms ensure the arborescent coherence of the corpus.

There are also "episodic" and unproductive terminological metaphors. The ability of a generic metaphor to develop new specialized meanings, lies, in general, in a relationship of close interdependence with the "components", with the specialization of the source domain, as it is not foreign to its "metaphysics". 


\section{Associated preconceptual patterns}

In the internal dynamics of the medical language, two or more preconceptual patterns can be used based on a logical relationship in order to form a new concept, which we fit in the class of metaphors created through interaction:

a. med. "bacteriorhodopsin" (Fr. bactériorhodopsine,f. n.; Ro. Bacteriorodopsină

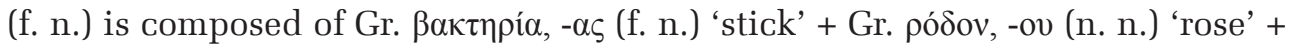

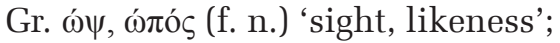

b. med. "cytotrophoblast" (Fr. cytotrophoblaste, m. n.; Ro. citotrofoblast, (n.

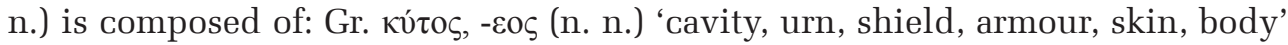

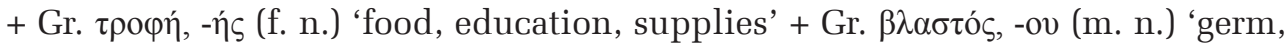
bud, yolk, son';

c. med. "cycloergometer" has the following elements at the structural level: Gr.

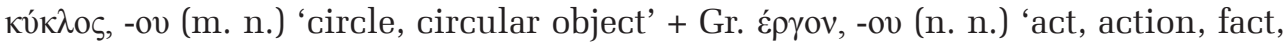

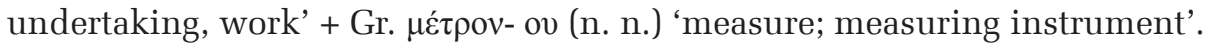

Methodologically, we propose the concept of "associated preconceptual pattern" in researching scientific compounds and/or polylexical metaphors. On the linguistic level, the compound brings about/designates the unequivocal "abstract image"/notion the associated metaphorical patterns propose through interaction. There are the conditions the associated metaphorical constructs respect in the process of creating conceptual systems, thus ensuring irreversible denominations: regime restrictions, the compatibility of elements, and monoreferentiality.

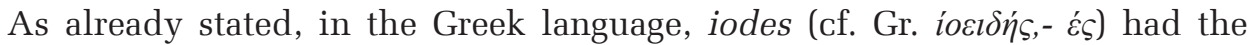
meaning of 'purple, sober'. Iod (cf. Fr. iode; En. iodine) is a teminological metaphor that has created several specific constructs (in medicine, in chemistry): Ro. iodofilie (cf. Fr. iodophilie; En. iodophilia), Ro. iodopsină (cf. Fr. iodopsine; En. iodopsin), Ro. iodotirozină (cf. Fr. iodotyrosine; En. iodotyrosine), Ro. iodoterapie (cf. Fr. iodothérapie; En. iodotherapy), etc. The conceptual field of such constructs gravitates around the constitutive metaphor and is created based on "regime" restrictions imposed by:

- the chromatic component: iodopsin has two conceptual models: iod ('violet') + opsia (cf. Gr. $\omega \dot{\psi} \iota \varsigma,-\varepsilon \omega \varsigma$ 'sight');

- aim: iodoform, antiseptic local: iod ('violet')+ Lat. formica ('ant');

- effect: iodotyrosine, which includes the derivatives of tyrosine: iod ('violet') + tyros ('cheese');

- the attraction of components: iodophilia: iod ('violet') + Gr. philo-, philein

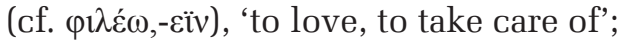

- action: iodotherapy ('iodine therapy').

The metaphorical constructs have a special impact upon the conceptual dynamics through the degrees of compatibility/cohesion of elements. 
Granulocytopenia is formed for example - based on the "compatible" feature -

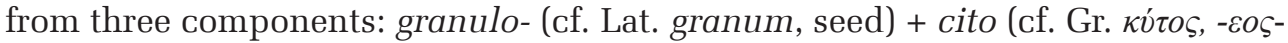
'breastplate, shield, cavity, cell') + penie (cf. Gr. $\pi \varepsilon v i \alpha,-a \tilde{\varsigma}$ - 'poverty, shortage'). Respecting the regime restrictions and the "compatible" feature of elements, granulocytopenia (defined as the decrease in the number of particles on the level of blood cells, cf. DM 2007: 343) is a metaphorical construct that carries autonomous cognitive/informational content. Here are some other examples: med. En. neuroblastoma (cf. Fr. granuloblastome; En. neuroblastoma; Ro. granuloblastom); En. granulocytosis (cf. Fr. granulocytose; En. granulocytosis; Ro. granulocitoză); med. En. granulopexic (cf. Fr. granulopexique, adj.; En. granulopexic; Ro. granulopexic ); med. En. granulopenia (cf. Fr. granulopénie; En. granulopenia; Ro. granulocitopenie), etc.

The metaphorical construct "ignipuncture" (cf. Fr. ignipuncture) is a metaphor formed through interaction, developed based on two compatible models, out of which "igni-" is strongly marked metaphorically: fire (cf. Lat. ignis, is 'torch, lightning, fire') + punctura ('sting'). The term is the signifier of the concept "cauterization of certain points... by applying the electrocautery" (DM 2007: 583). The "compatible" feature allows the creation of a double filter: one and the same medical concept satisfies simultaneously - on the level of the compound - both metaphorical models (ignipuncture - sting with fire). At this point, the denomination of scientific compounds differs from the category of metaphors existing in lexical compounds, where connotation does not satisfy the two associated terms separately: Ro. Barbăneagră ('black beard'), Ro. Fruntelată ('wide forehead') have become surnames; Ro. coate-goale ('bare elbows'), Ro. mațe-fripte ('roasted guts') have stylistic values. The effects are also different: in the case of the interactional metaphors, the effect is strictly cognitive; in relation to signification and representation, the effect of lexical compounds can be iconic, subjective, stylistic, and partially cognitive.

The idea of the metaphorical value of compounds is not new. It has been applied mainly on the lexicon. Michael Bréal highlighted the contribution of the metaphor to the enriching of the common lexicon (Bréal 1897). K. Bühler notes that any linguistic compound is somewhat metaphorical... (Bühler, Italian translation: 402). In DSL, Angela Bidu-Vrânceanu remarks the fact that several compounds have stylistic values (Dicționar de Ştiințe ale limbii, 2001: 125).

The differences between the notions having the same model are established from the semantical point of view, using the instruments available to every historical language. After getting to know himself, the scientist started differentiating objects, naming and systematizing them based on the conceptual field and the degree of compatibility. He developed the necessary differences between the parts of the whole. 


\section{Associated patterns in canonical titling}

In Egyptian writings, the identity of the medical man overlapped with that of the priest, the scribe, this fact being recorded in terms such as: "priest-doctor", "scribe-doctor", the divine patron being Thoth, whose epithet was ph-ar-maki ('the one who ensures security'). The metaphorical construct survived in the Gr. pharmakon (vb. phero 'to bear, to bring', nouns pharma and pharmacon), a quasi-universal root in current pharmaceutical terminology. The everyday life of Greeks and Romans from the time of Hippocrates has left a strong mark on medical language. After the death of Alexander the Great in 323 B.C., the scientific centre would move from Greece to Alexandria, and then to Rome.

Detaching itself from magic and witchcraft, medicine accomplished the transition from empirical practices to scientific methods: the Gr. iatros designated the doctor pharmacist, whose activity was bound to his residence, iatreion ('medical office'). The root iatro- developed the idea of a doctor. The person of the doctor in the European tradition has a major role in associated canonical procedures of titrating. The quasi-universal root iatros has become the matrix for several metaphorical constructs: paediatrics, cosmiatry, iatrochemsitry, etc.

The generic name of the subdomain/of the scientific field invokes, however, a varied and complex discursive strategy, always motivated and in most cases developed based on a binary pattern. The relations between the title-name of the domain/subdomain and the cognitive discourse (terminographic/specialized text) are usually ones of interdependence. The title metaphor (of a conceptual nature) marks the belonging of the "discourse" to a certain domain of scientific knowledge that individualizes it. It represents a parameter with an indicative goal: it is the element that indicates the selection operated by the scientiest in the labyrinthine, hard-to-delimit universe of abstract knowledge. The title metaphor has become a logical operating tool, of selecting and individualizing information on the macrostructural level of specialized languages. The organizing/regulating operation of relationships between the title metaphor and the domain/branch cannot be achieved outside the conative function of the former, of the "title" in general (Leo Hoek 1972: 291). This involves centring the message on the recipient: the generic name of Cardiology becomes an individualizing, quasi-independent element of the medical subdomain that allows selecting the area of interest of the researcher/ practitioner and the one that mediates the access (directly or indirectly) to a coherently organized conceptual sphere. Pneumology is a subdomain constructed on the "scheme-image" - pneuma - that gives the name of the discipline. The metaphorical model underpinning the name of anatomy is "dissection" (cf. Gr. $\alpha \dot{v} \alpha \tau o \mu \eta \dot{\eta},-\tilde{n} \varsigma)$. Compared to the language of social and human sciences, where the title/name indicates aesthetic parameters (Expressionism, Impressionism), movement (Realism, Romanticism), temporality in the historical sense (the 
History of the Middle Ages), philosophical orientation (Idealism, Nihilism), sciences such as medicine, economics, etc. have a special situation due to the fact that the name of the subdomain/of the branch is usually a metaphor formed based on associated preconceptual patterns. Hence the cryptic nature of such languages. The title metaphor physical therapy "treatment based on energy forms from the nature" establishes logical relations with individualized key metaphors of the branch: Ro. electroterapia (cf. Fr. électrothérapie; En. electrotherapeutice, electrotherapy), Ro. fototerapia (cf. Fr. photothérapie; En. phototherapy), Ro. hidrotermoterapia (cf. Fr. hydrothérapie; En. hydrotherapy), kinotherapy, thalassotherapy, crenotherapy. Individualizing the scientific domains through the title metaphor started in French medicine in the $16^{\text {th }}$ and $17^{\text {th }}$ centuries. The $18^{\text {th }}$ century brought about the first conceptual changes through the consecration of great masters in French clinics. The meanings of several key-terms were clarified. This represents the first moment where scientific medicine is outlined (Rusu 2007: 32) through the activity of geniuses such as Louis Pasteur and Claude Bernard. The $19^{\text {th }}$ and $20^{\text {th }}$ centuries impose several other generic metaphors, clearly denoting the avant-garde medical branch or specialization of the scientist. The name of the medical subdomain complies with the epistemologically imposed strategies: the title metaphor is a bi-member unity, offering conceptual information through the prefix-like element, and through logos, the intrinsic order of the scientist's way of thinking (philology, biology). The differences in strategy are imposed by the relationship between general and particular.

Judged by the criterion of occurrence and dispersion, in the medical language, the compounds formed with logos are generic constructs of the subdomain: rheuma+logy, cario+logy, entero+logy, etc. We can see from the examples above that logos represents one of the numerous linguistic elements through which the scientific domain interacts with another, in the general context of knowledge. It is an element of interdisciplinarity: the medical language is not simply a "product" of medicine. Logos, logia are two elements that sustain the idea of existence in a unique space of knowledge, whose future developments can be found on the level of different types of terminology. The title/canonical metaphor proves a double functionality: 1 . it serves to name a certain domain/subdomain; 2 . it transparentizes meaning that science does not use complicated titles the way the literary discourse does.

The title metaphor of the subdomain is connected to the cognitive content in the traditional branches of European medicine through several other conceptual constructs: the subdomain of "microbiology" in relation to the branches of "bacteriology", "mycology", "protozoology", "virology", "parasitology", and "algology". 


\section{Non-canonical titling and the medicine of the future}

At each stage in the evolution of science, there is a certain way of titling in solidarity with the level of knowledge, with vanguard technology. In the $20^{\text {th }}$ century, doctors use the latest findings in the technical domain, while the title metaphor focuses on the medical procedure + the branch: "nanosurgery". The role of the doctor seems to have been taken over by technique: microsurgery, nano/ surgery/laser, etc. We do not find in the practice of titling canonical schemes of the title metaphor, in which logos and iatroi had a priority in usage. In generic names, technical procedures are more and more frequent. In new branches of current medicine, the substitution of doctor with procedure, of subject with object is omnipresent, being associated with numerous techniques of intervention. This constant indicates a true supremacy of informatics, an authority exercised through the usage of the computer. The title metaphor results in a gap, a delimitation needed by a classical cognitive pattern in the conceptual system, as opposed to a postmodern cognitive pattern. Once defined, such cognitive patterns show several developments with an arborescent function, in conjunction with other types of metaphorical constructs, in scientific compounds that have become a source of neonymy on the level of specialized languages.

\section{References}

Breal, M. 1897. Michael Bréal Essai de sémantique. Hachette, Paris.

Buhler, K. 1934. Sprachtheorie. Gustav Fischer Verlang, Jena, Stuttgart. Theory of language: The representational function of language. Transl. D. P. Goodwin. Amsterdam, John Benjamins.

Hoek, L. 1972. Description d' un archonte: Preliminaires a une theorie du titre a partir du Nouveau Roman, în Nouveau Roman: hier, aujourd hui. Union Generale d`edition, Paris.

\section{Sources}

Andrei, N. 1987. Dicționar etimologic de termeni ştiințifici - Elemente de compunere greco-latine. Editura Ştiințifică şi Enciclopedică, Bucureşti.

Bidu-Vrănceanu, A. et al. 2005. Dicționar de Ştiințe ale limbii. Editura Nemira, Bucureşti, 2005.

Dorland 2003. Dorland's illustrated medical dictionary. 